\title{
A Role for Notch Signaling in Human Corneal Epithelial Cell Differentiation and Proliferation
}

\author{
Aibua Ma, ${ }^{1,2}$ Mike Boulton, ${ }^{3}$ Bojun Zhao, ${ }^{4}$ Che Connon, ${ }^{1,2}$ Jun Cai, ${ }^{3}$ and Julie Albon ${ }^{1,2}$
}

Purpose. To identify the role of Notch signaling in the human corneal epithelium.

Methods. Localization of Notch1, Notch2, Delta1, and Jagged1 in the human corneal epithelium was observed with the use of indirect immunofluorescence microscopy. Gene and protein expression of Notch receptors and ligands in human corneal epithelial cells was determined by RT-PCR and Western blot analysis, respectively. The effects of Notch inhibition (by $\gamma$-secretase inhibition) and activation (by recombinant Jagged1) on epithelial cell proliferation (Ki67) and differentiation (CK3) were analyzed after Western blotting and immunocytochemistry.

Results. Immunofluorescent labeling localized Notch1 and Notch2 to suprabasal epithelial cell layers, whereas Delta1 and Jagged1 were observed throughout the corneal epithelium. Notch1, Notch2, Delta1, and Jagged1 genes and proteins were expressed in human corneal epithelial cells. $\gamma$-Secretase inhibition resulted in decreased Notch1 and Notch2 expression, with an accompanying decrease in $\mathrm{Ki} 67$ and increased CK3 expression. The activation of Notch by Jagged 1 resulted in the upregulation of active forms of Notch1 and 2 proteins $(P<$ $0.05)$, with a concurrent increase in $\mathrm{Ki67}(P<0.05)$ and a decrease in CK3 $(P<0.05)$ expression. Interestingly, $\gamma$-secretase inhibition in a three-dimensional, stratified corneal epithelium equivalent had no effect on $\mathrm{Ki} 67$ or CK3 expression. In contrast, Jagged 1 activation resulted in decreased CK3 expression $(P<0.05)$, though neither Notch activation nor inhibition affected cell proliferation in the $3 \mathrm{D}$ tissue equivalent.

Conclusions. Notch family members and ligands are expressed in the human corneal epithelium and appear to play pivotal roles in corneal epithelial cell differentiation. (Invest Opbthalmol Vis Sci. 2007;48:3576-3585) DOI:10.1167/iovs.06-1373

$\mathrm{T}$ he Notch signaling pathway controls diverse cellular processes, including differentiation, proliferation, apoptosis, cell-cell adhesion, and migration events through local cellcell interactions. ${ }^{1-3}$ In higher vertebrates, multiple Notch ho-

From the ${ }^{1}$ Cell and Molecular Biology Unit, School of Optometry and Vision Sciences, and the ${ }^{2}$ Cardiff Institute of Tissue Engineering and Repair, Cardiff University, Cardiff, United Kingdom; the ${ }^{3}$ Department of Ophthalmology and Visual Sciences, University of Texas Medical Branch, Galveston, Texas; and ${ }^{4}$ Biological Sciences, Lancaster University, Lancaster, United Kingdom.

Supported by the National Eye Research Centre, UK, and by an Overseas Research Studentship Award (AM).

Submitted for publication November 14, 2006; revised March 4, 2007; accepted June 8, 2007.

Disclosure: A. Ma, None; M. Boulton, None; B. Zhao, None; C. Connon, None; J. Cai, None; J. Albon, None

The publication costs of this article were defrayed in part by page charge payment. This article must therefore be marked "advertisement" in accordance with 18 U.S.C. $\$ 1734$ solely to indicate this fact.

Corresponding author: Julie Albon, Cell and Molecular Biology Unit, School of Optometry and Vision Sciences, Cardiff University, Maindy Road, Cardiff, Wales, UK CF24 4LU; albonj@cardiff.ac.uk. mologues have been identified, including Notch 1 to Notch 4 in rodents and humans. ${ }^{4-7}$ Notch1 and Notch2 have the highest homology with each other, whereas Notch3 and Notch4 slightly diverge structurally from Notch 1 and Notch 2 in extracellular and intracellular domains. The intracellular domain of Notch is known to act as a transcriptional activator and is often referred to as activated Notch. ${ }^{1-3}$

Multiple ligands for the Notch receptors are identified in mammals (Jagged1/Serrate1, Jagged2/Serrate2, Delta1, Delta3, and Delta4). Delta1, Jagged1, and Jagged2 have been characterized as ligands for Notch1, Notch2, and Notch3 receptors. $^{8-12}$ The Notch receptor undergoes a ligand-dependent extracellular cleavage that releases the extracellular domain, leaving a membrane-tethered intracellular domain. ${ }^{13}$ Subsequent intramembrane cleavage by $\gamma$-secretase $e^{1,14-17}$ results in the translocation of the Notch intracellular domain to the nucleus, where it influences the decision of cell fate. ${ }^{1,14-17}$ It is generally believed that Jagged and Delta act as transmembrane proteins that interact with Notch receptors expressed on adjacent cells. ${ }^{2}$

Maintenance of corneal structure is crucial for its physiological functions in biodefense and as a refractive tissue. ${ }^{18}$ The corneal epithelium is dependent on its constant renewal through slow-cycling stem cells at the limbus and the centripetal migration of transient amplifying cells. ${ }^{19}$ Cell proliferation, differentiation, and stratification are essential to this process. However, precise mechanisms that regulate these processes have yet to be fully elucidated, and cell interaction is an important component.

In this study, we have demonstrated the presence of Notch receptors and their ligands in the human corneal epithelium. Furthermore, we have shown that the Notch signaling pathway regulates cell differentiation in the human corneal epithelium.

\section{Methods}

\section{Source of Tissue}

Human donor corneoscleral disks and eyes (within 24 hours of cadaver time) were obtained from the UK Corneal Transplant Service Eye Bank (Bristol, UK). Mean age of donors was $62 \pm 19$ years. Human donor tissue was used in accordance with the tenets of the Declaration of Helsinki.

\section{Immunolocalization of Notch Receptors and Their Ligands in Human Corneas}

Corneas were snap frozen in liquid nitrogen-cooled isopentane and embedded in optimum cutting temperature (OCT) compound. Cryostat sections $(7 \mu \mathrm{m})$ were prepared, fixed for 15 minutes at room temperature with $4 \%$ paraformaldehyde, and permeabilized for 15 minutes in $0.2 \%$ Triton X-100. After three washes with PBS, the sections were incubated for 2 hours with primary antibodies (diluted 1:100 in PBS) directed against Notch1, Notch2, Delta1, and Jagged1. After three 10-minute washes in PBS, the sections were incubated for 
TABle 1. Primer Sequences for RT-PCR

\begin{tabular}{|c|c|c|c|}
\hline Gene & Primer Sequence & $\begin{array}{c}\text { Annealing } \\
\text { Temperature } \\
\left({ }^{\circ} \mathrm{C}\right)\end{array}$ & $\begin{array}{c}\text { Product } \\
\text { Amplified } \\
\text { (bp) }\end{array}$ \\
\hline Notch1 & $\begin{array}{ll}\mathrm{F}: & 5^{\prime} \text {-GACATCACGGATCATATGGA - 3' } \\
\mathrm{R}: & 5^{\prime}-\mathrm{CTCGCATTGACCATTCAAAC}-3^{\prime}\end{array}$ & 50 & 666 \\
\hline Notch2 & $\begin{array}{l}\text { F: } 5^{\prime} \text {-CCAGAATGGAGGTTCCTGTA - 3' } \\
\text { R: } \text { 5'-GTACCCAGGCCATCAACACA - 3' }^{\prime}\end{array}$ & 52 & 377 \\
\hline Notch3 & $\begin{array}{l}\mathrm{F}: \text { 5'-CACTGAAGGCTCGTTCCA - 3' } \\
\mathrm{R}: \quad 5^{\prime}-\text { GGTTGCTCTCGCATTCA - 3' }\end{array}$ & 50 & 202 \\
\hline Notch4 & $\begin{array}{ll}\mathrm{F}: & 5^{\prime} \text {-AGCCGATAAAGATGCCCA - 3' } \\
\mathrm{R}: & 5^{\prime} \text {-ACCACAGTCAAGTTGAGG - 3' }\end{array}$ & 50 & 687 \\
\hline Delta1 & 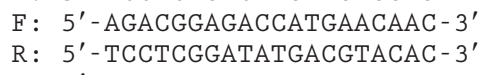 & 52 & 382 \\
\hline Delta3 & $\begin{array}{ll}\mathrm{F}: & 5^{\prime} \text {-GTGAATGCCGATGCCTAGAG } \\
\mathrm{R}: & 5^{\prime} \text {-GGTCCATCTGCACATGTCAC - 3' }\end{array}$ & 54 & 256 \\
\hline Delta4 & 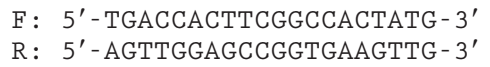 & 50 & 620 \\
\hline Jagged1 & $\begin{array}{ll}\mathrm{F}: & 5^{\prime} \text {-AGTCACTGGCACGGTTGTAG-3' } \\
\mathrm{R}: & 5^{\prime} \text {-TCGCTGTATCTGTCCACCTG-3' }\end{array}$ & 54 & 227 \\
\hline Jagged 2 & $\begin{array}{ll}\mathrm{F}: & \text { 5'-GATTGGCGGCTATTACTGTG-3' } \\
\mathrm{R}: & \text { 5'-AGGCAGTCGTCAATGTTCTC - 3' }\end{array}$ & 52 & 600 \\
\hline$\beta$-actin & $\begin{array}{ll}\mathrm{F}: & 5^{\prime}-\mathrm{CATCACCATTGGCAATGAGC}-\text { 3' }^{\prime} \\
\mathrm{R}: & 5^{\prime} \text { - CGATCCACACGGAGTACTTG - 3' }\end{array}$ & 58 & 284 \\
\hline
\end{tabular}

F, forward; R, reverse; bp, base pairs.

2 hours in appropriate (1:1000 in PBS) secondary antibodies (Alexa Fluor 488; Molecular Probes, Eugene, OR). After another three washes with PBS, the sections were mounted in mounting medium (Hydromount; BDH, Poole, UK) containing bis-benzamide (Hoechst 33342; 1 in 500 dilution of $1-\mathrm{mg} / \mathrm{mL}$ stock solution). Substitution of the primary antibodies with same-species serum or elimination of primary antibody served as negative controls. The sections were visualized, and images were captured as described.

\section{Isolation and Culture of Human Corneal Epithelial Cells}

Corneoscleral rims were cut into 1- to 2-mm explants that were placed epithelial-side down in six-well culture plates. The explants were maintained at $37^{\circ} \mathrm{C}$ in a growth medium consisting of a $1: 1$ mixture of Dulbecco modified Eagle medium (DMEM)/Ham F-10 medium supplemented with 5\% FCS, 5\% donor horse serum, $0.5 \%$ dimethyl sulfoxide
FIGURE 1. Immunolocalization of Notch1, Notch2, Delta1, and Jagged1 in human cornea. (a-f) Notch1 and Notch2 were immunolocalized to suprabasal cell layers of the corneal epithelium but were not detected in superficial surface cells or basal cell layers of the central, peripheral, or limbal region. (g-1) Delta1 and Jagged1 were expressed throughout all cell layers of the central, peripheral, and limbal epithelium. (m-o) Immunoreactivity was not detected in control corneal sections, processed with same species serum or PBS, in place of primary antibodies. Blue: Hoechst nuclear localization. Bar, $50 \mu \mathrm{m}$.

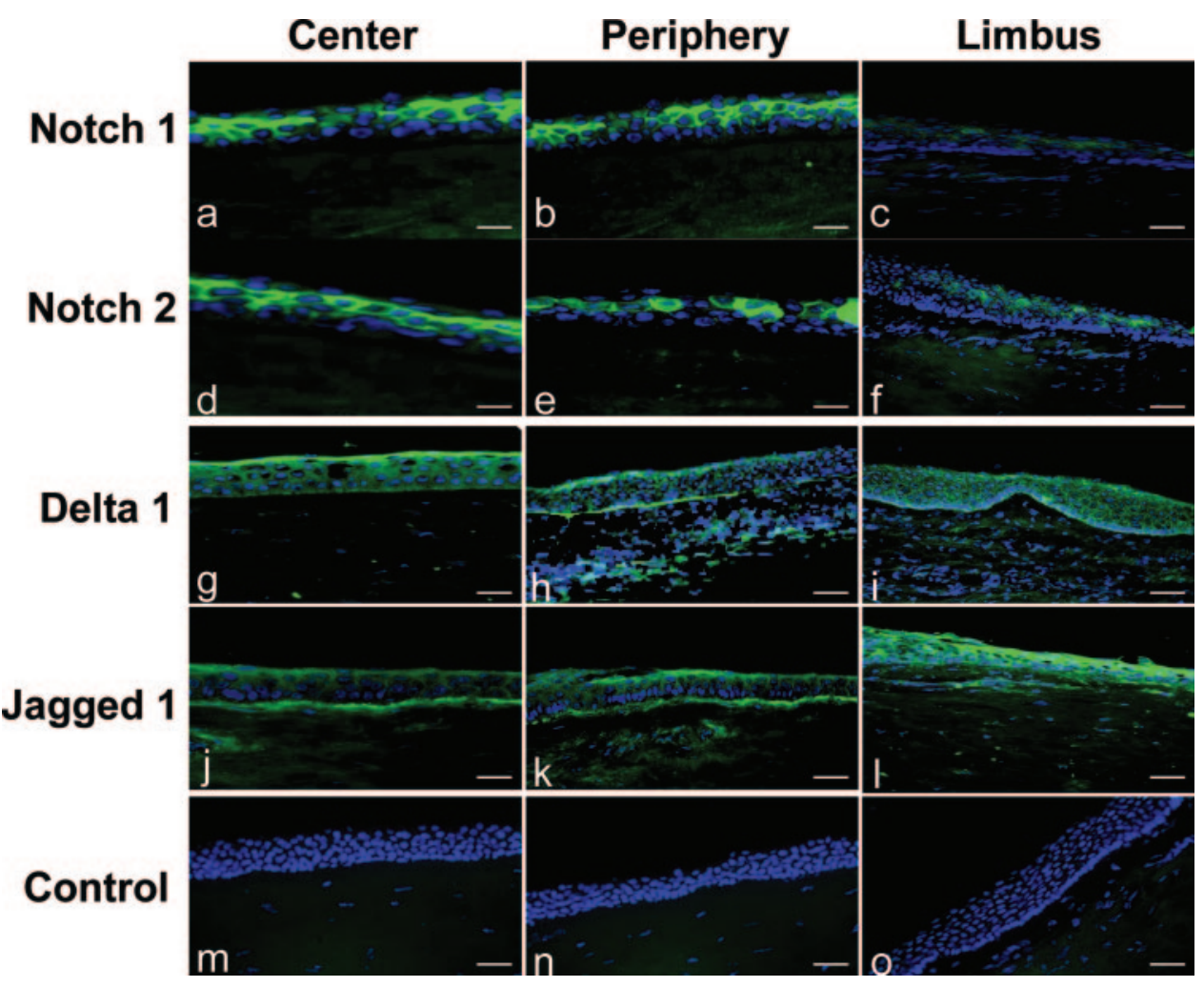


(DMSO), $5 \mu \mathrm{g} / \mathrm{mL}$ insulin, $2.5 \mu \mathrm{g} / \mathrm{mL}$ fungizone, $0.1 \mu \mathrm{g} / \mathrm{mL}$ cholera toxin, $100 \mu \mathrm{g} / \mathrm{mL}$ streptomycin, $100 \mu \mathrm{g} / \mathrm{mL}$ kanamycin, $100 \mathrm{U} / \mathrm{mL}$ benzyl penicillin, and $2 \mathrm{mM}$ glutamine. Growth medium was changed every 2 to 3 days, and explants were removed after epithelial cell outgrowth. Primary epithelial cells were used in all experiments. The purity of epithelial cell cultures was confirmed by positive immunostaining for the epithelial cell differentiation marker cytokeratin 3 (CK3). ${ }^{20}$

\section{RT-PCR Analysis of Notch Receptors and Ligands}

Total RNA was isolated from cultured epithelial cells using phenolguanidine isothiocyanate reagent (TRIzol; Invitrogen, Glasgow, UK) and was subjected to RT-PCR (First-Strand Synthesis Kit; Abgene, Epsom, UK) and PCR (ReddyMix; Abgene) according to the manufacturer's instructions. RNA concentration was determined spectrophotometrically, and an equal quantity of total RNA was used for each sample. PCR primers for Notch receptors (Notch1-Notch4) and their ligands (Delta1, Delta3, Delta4, Jagged1, Jagged2) were designed according to the gene sequences obtained from GenBank. Primer sequences, required annealing temperatures, and sizes of expected PCR products are detailed in Table 1. cDNA was amplified (PCR Master Mix; Applied Biosystems, Foster City, CA). Each cycle consisted of 20 seconds at $94^{\circ} \mathrm{C}, 30$ seconds at the defined temperature (Table 1), 60 seconds at $72^{\circ} \mathrm{C}$, and a final extension at $72^{\circ} \mathrm{C}$ for 7 minutes. $\beta$-Actin was used as a positive control. PCR products were electrophoresed on a $1.2 \%$ agarose gel containing ethidium bromide and visualized under UV light.

\section{Western Blot Analysis of Notch Receptors and Ligands, Ki67, and CK3 Expression}

Corneal epithelial cells were lysed by shaking at $4{ }^{\circ} \mathrm{C}$ for 30 minutes in RIPA buffer ( $50 \mathrm{mM}$ Tris-HCl, 1\% NP-40, 0.25\% Na-deoxycholate, 150 $\mathrm{mM} \mathrm{NaCl}, 1 \mathrm{mM} \mathrm{Na} \mathrm{VO}_{4}$, and $\mathrm{NaF}$ ) containing protease inhibitors (1 $\mu \mathrm{g} / \mathrm{mL}$ each of aprotinin, leupeptin, pepstatin, EDTA, phenyl methyl sulfonyl fluoride [PMSF]). Remnants were detached using a cell scraper, and lysates were transferred to Eppendorf tubes and centrifuged at $12000 \mathrm{~g}$ for 15 minutes at $4^{\circ} \mathrm{C}$. The supernatant was transferred to a new microfuge tube, mixed with sample buffer $(12 \mathrm{mM}$ Tris- $\mathrm{HCl}$, $96 \mathrm{mM}$ glycine, $10 \%$ SDS, $1 \%$ 2-mercaptoethanol, and $0.1 \%$ bromophenol blue, $\mathrm{pH}$ 6.8), and boiled for 5 minutes. Total protein was determined by the BCA protein assay (Pierce, Rockford, IL), and equal protein concentrations were loaded onto an $8 \%$ polyacrylamide gel using a 5\% stacking gel. Samples, containing equal protein loadings, were subjected to SDS-PAGE. Resolved proteins were transferred to a nitrocellulose membrane and were probed with anti-human Notch1 (1:200), Notch2 (1:200), Jagged1 (1:200), Delta1 (1:200; all from Santa Cruz Biotechnology, Autogen-BioClear, UK), rabbit anti-Ki67 (1:100; DakoCytomation, Glostrup, Denmark), and monoclonal anti-CK3 (1: 200; MP Biomedicals, Inc, Aurora, OH) antibodies for 2 hours at room temperature, followed by incubation for 1 hour in appropriate secondary antibodies conjugated with horseradish peroxidase (HRP; 1:1000; Santa Cruz Biotechnology, Santa Cruz, CA). The enhanced chemiluminescence (ECL) system (Santa Cruz) was used to develop immunopositive bands.

\section{Effect of Inhibition and Activation of Notch on Corneal Epithelial Cell Differentiation and Proliferation}

$\gamma$-Secretase inhibitor (LY L685458, Sigma-Aldrich, Poole, UK) and recombinant Jagged1 (rJagged1; R\&D Systems, Minneapolis, MN) as an activator were used to evaluate the function of Notch signaling in the regulation of epithelial cell differentiation and proliferation. Subconfluent epithelial cells $(800,000$ cells/well) were incubated in serumfree medium for 1 hour, then incubated in medium containing either $\gamma$-secretase inhibitor $(25 \mu \mathrm{M}$ or $50 \mu \mathrm{M})$ for 4 hours or Jagged $1(5 \mu \mathrm{M}$ or $10 \mu \mathrm{g} / \mathrm{mL}$ ) for 2 days. Concentrations of $\gamma$-secretase inhibitor and
Jagged1 were chosen because of their previously reported respective inhibitory and stimulatory effects on the Notch pathway.9,21 Control wells were incubated in medium containing either $0.2 \%$ dimethyl sulfoxide (DMSO) or 1\% PBS. The expressions of Notch1, Notch2, Ki67, and CK3 were semiquantified after scanning densitometry (Expression 1680 scanner; Epson, Long Beach, CA) of immunopositive blots using imaging software (Image; Scion Corporation, Frederick, MD).

\section{Immunolocalization of Notch Receptors and Ligands in Corneal Epithelial Cells}

Human corneal epithelial cells were cultured on coverslips, precoated with attachment factor (TCS CellWorks, Buckingham, UK), until subconfluence was reached. Then the cells were treated with $\gamma$-secretase inhibitor or Jagged 1 in triplicate wells as described. After fixation in 1\% paraformaldehyde (PFA) for 20 minutes and two washes in PBS, the cells were permeabilized by $0.2 \%$ Triton-X-100 for 20 minutes. Nonspecific binding sites were blocked by $5 \%$ milk in PBS for 30 minutes, after which the cells were incubated with Notch1 (1:100), Notch2 (1:100), Ki67 (1:50), and CK3 (1:100) antibodies for 2 hours at room temperature; this was followed by three washes in PBS and a 2-hour incubation in Alexa Fluor 488 or 594 secondary antibodies (each at 1:1000 dilution in PBS, Molecular Probes, UK). After three more washes with PBS, the cells were mounted in a water-based mounting medium (Hydromount; National Diagnostics, Atlanta, GA) containing bis-benzamide (Hoechst 33342, 1 in 500 dilution of $1 \mathrm{mg} / \mathrm{mL}$ stock

A
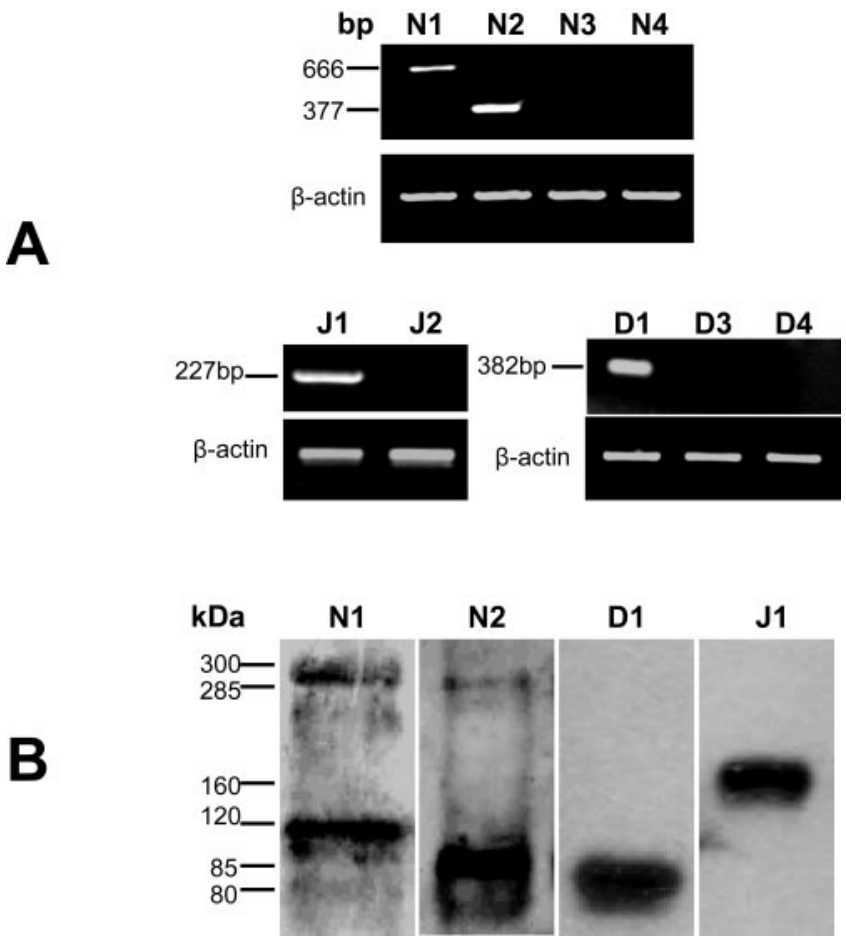

FIGURE 2. Expression of Notch family members in corneal epithelial cells. (A) Total RNA was isolated from cultured human corneal epithelial cells. RT-PCR was performed and PCR products were electrophoresed in a $1.2 \%$ agarose gel containing ethidium bromide and visualized under UV light. Notch1 (N1), Notch2 (N2), Delta1 (D1), and Jagged1 (J1) mRNA were expressed by human corneal epithelial cells. However, Notch3 (N3), Notch4 (N4), Delta3 (D3), Delta4 (D4), and Jagged2 (J2) mRNA were not detected. $\beta$-Actin was amplified as a positive control. (B) Protein expression of Notch1, Notch2, Delta1, and Jagged1 were identified in corneal epithelial cell lysates. Full-length and truncated isoforms of Notch1 and Notch2 were identified. 
solution). Substitution of the primary antibodies with same-species nonimmune serum served as negative control. Experiments, in triplicate, were repeated at least twice. Images were captured digitally in five random microscope fields from each sample with the appropriate software (QFluoro; Leica Microsystem AG, Wetzlar, Germany) under a wide-field microscope (DMRAZ; Leica).

The percentage of positively labeled cells was analyzed with image analysis software (Image Pro-Plus; Image Solutions, UK) by an observer who was masked to treatment group allocation; particular care was taken to identify nuclear and membrane-associated nonnuclear labeling. The total number of cells was determined by counting the Hoechst-labeled nuclei. Hoechst-labeled nuclei were then removed from the image, and the number of cells, with positively labeled cell membranes, including cell borders, was determined. The number of immunopositive-labeled nuclei was quantified in a similar fashion.

\section{Notch Signaling in Corneal Epithelial Cell Stratification}

Corneal epithelial cells were cultured according to the air-lift stratification method described by Koizumi et al. ${ }^{22-24}$ In brief, corneoscleral rims were cut into six pieces, and the posterior endothelial-stromal explant was excised and discarded. The remaining epithelial-stromal explant was placed, epithelial side down, onto the amniotic membrane (AM) in a culture insert, with $3.0 \times 10^{4}$ cells $/ \mathrm{cm}^{2}$ mitomycin-treated 3T3 fibroblasts (NIH 3T3 fibroblast cell line, European collection) in the lower chamber. Each explant was cultured while submerged in
SHEM media (DMEM/F-12 1:1 mixture, FBS $10 \%$, insulin $5 \mathrm{mg} / \mathrm{mL}$, cholera toxin $0.1 \mathrm{nM}$, epidermal growth factor $10 \mathrm{ng} / \mathrm{mL}$, and penicillin-streptomycin $50 \mathrm{IU} / \mathrm{mL}$ ) to promote epithelial cell outgrowth. At 7 days, epithelial cell cultures were incubated in SHEM containing $0.2 \%$ FBS for 4 hours at $37^{\circ} \mathrm{C}$. The wells were rinsed with PBS twice and were cultured in control media (SHEM $\pm 0.2 \%$ DMSO), $10 \mu \mathrm{g} / \mathrm{mL}$ rJagged 1 in SHEM, or $50 \mu \mathrm{M} \gamma$-secretase inhibitor in SHEM $+0.2 \%$ DMSO for another 1, 2, or 3 weeks, with cultures air lifted in the final (fourth week) by reducing the level of media to expose the epithelial cell surface to air, thus promoting epithelial stratification.

Cultures were snap-frozen in liquid nitrogen-cooled isopentane and were cryosectioned as described before. They were subjected to immunofluorescent localization of Notch1, Notch2, Ki67, and CK3, as described. The number of cells, labeled positively for Ki67, CK3, or Hoechst, was analyzed, by a masked observer (Image Pro-Plus; Image Solutions). The percentage of Ki67- and CK3-labeled cells was expressed as a percentage of Hoechst-labeled nuclei. To examine corneal epithelial morphology, sections were stained using a standard histologic stain, hematoxylin and eosin.

\section{Statistical Analysis}

All experiments were repeated at least twice, and the results were expressed as mean \pm SEM. Statistical analysis was performed using one-way ANOVA or Kruskal-Wallis, dependent on distribution of data. $P<0.05$ was considered statistically significant.
A
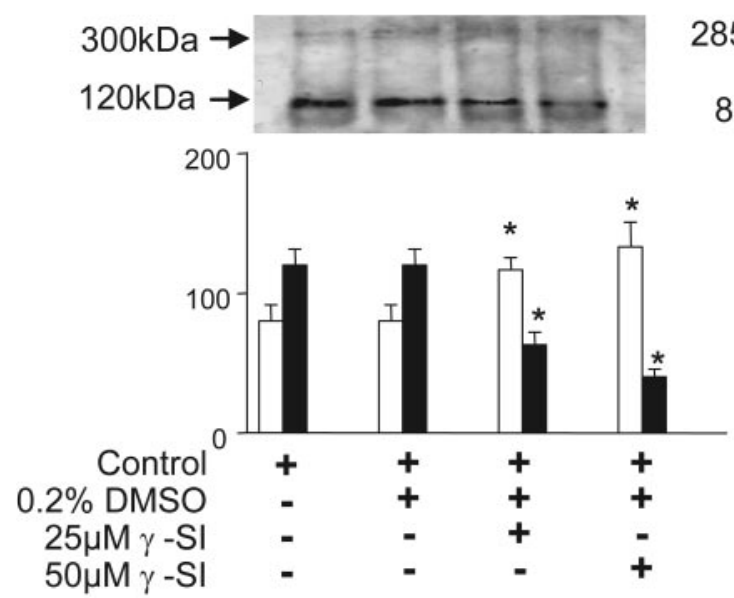

Figure 3. $\gamma$-Secretase inhibition of Notch1 and Notch2 in corneal epithelial cells. Cultured corneal epithelial cells were incubated with $\gamma$-secretase inhibitor $(25 \mu \mathrm{M}$ or 50 $\mu \mathrm{M} \gamma$-SI) or control media, with or without vehicle $(0.2 \% \mathrm{DMSO})$, for 4 hours. Lysates were resolved by SDSPAGE, and immunopositive bands were semiquantified by scanning laser densitometry. (A) Notch1 (fulllength: N1-300, white; NICD: N1120, black). (B) Notch2 (full-length: N2-285, white; NICD: N2-85, black). (C) Ki67. (D) CK3. Data are expressed as mean \pm SEM. ${ }^{*} P<$ 0.05 .
C

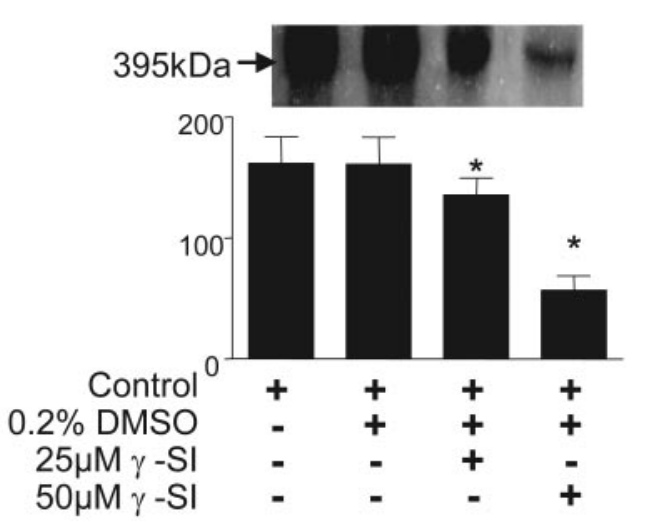

B

Notch2

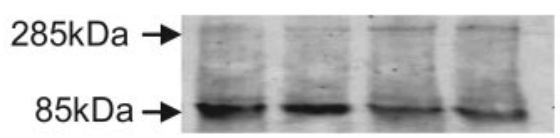

150

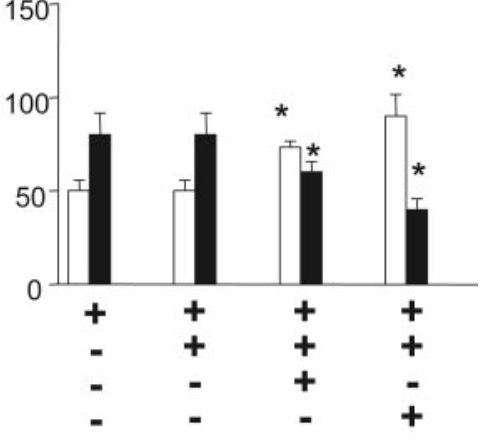

D

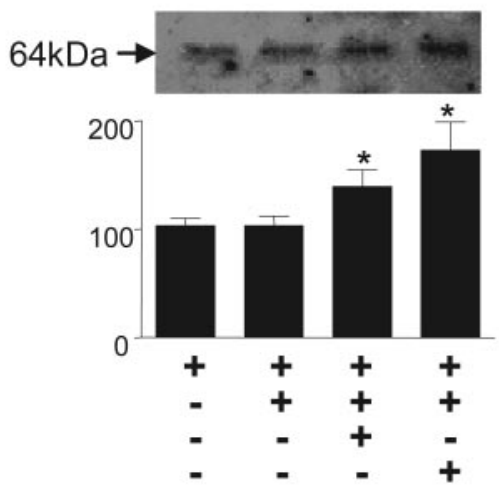




\section{Results}

\section{Immunolocalization of the Expression of Notch Receptors and Their Ligands in Human Cornea}

The spatial distribution of Notch receptors and their ligands in human corneas was identified after immunolocalization of Notch1, Notch2, Delta1, and Jagged1. Notch1 and Notch2 were localized to suprabasal cells in central, peripheral, and limbal regions of the cornea (Figs. 1a-f) but were absent from the basal cell layer in all regions. The surface superficial epithelial cells also appeared to lack Notch labeling. Delta1 and Jagged1 were localized throughout all cell layers in the central, peripheral, and limbal epithelium (Figs. 1g-1). Immunoreactivity was not detected in negative control slides (Figs. 1m-o).

\section{Gene and Protein Expression of Notch Receptors and Ligands in Corneal Epithelial Cells}

RT-PCR identified expression of the genes for the Notch receptors Notch1 and Notch2 and their ligands Delta1 and Jagged1 in cultured human corneal epithelial cells (Fig. 2A). Gene expression of Notch3, Notch4, Delta3, Delta4, and Jagged2 was not detected (Fig. 2A).

Protein expression was confirmed by Western blotting. The active Notch intracellular domain (NICD) and full-length isoforms of Notch1 and Notch2 and ligands Delta 1 and Jagged 1 were identified in primary passage-cultured epithelial cell lysates according to their molecular weights after immunoblotting, as demonstrated in Figure 2B: Notch1 NICD (Notch1$120,120 \mathrm{kDa}$ ), full-length Notch1 (Notch1-300, $300 \mathrm{kDa}$ ), Notch2 NICD (Notch2-85, $85 \mathrm{kDa}$ ), full-length Notch2
(Notch2-285, $285 \mathrm{kDa})$, Delta1 (80 kDa), and Jagged1 (160 $\mathrm{kDa})$.

\section{Inhibition of Notch Signaling Decreased Epithelial Cell Proliferation and Increased Cell Differentiation}

Exposure of cultured corneal epithelial cells to a $\gamma$-secretase inhibitor, which blocks cleavage of the intracellular domain of the Notch receptor, resulted in decreased expression of active NICD Notch1-120 (Fig. 3A) and Notch2-85 (Fig. 3B) and increased the expression of full-length Notch1-300 (Fig. 3A) and Notch2-285 (Fig. 3B) proteins. Alterations in protein expression appeared to be dose dependent such that levels of expression were significantly altered with a concentration of $\gamma$-secretase inhibitor from 0 to $25 \mu \mathrm{M}$ to $50 \mu \mathrm{M}$. These differences were statistically significant at $25 \mu \mathrm{M}(P<0.05)$ and 50 $\mu \mathrm{M}(P<0.05) \gamma$-secretase inhibitor treatment. The $\gamma$-secretase inhibitor also resulted in significantly decreased expression of Ki67 (Fig. 3C; $P<0.05$ ), a marker of actively cycling cells, ${ }^{25}$ and increased expression of the cornea-specific epithelial differentiation marker $\mathrm{CK}^{26}$ (Fig. 3D; $P<0.05$ ). These effects were greatest after treatment with $50 \mu \mathrm{M} \gamma$-secretase inhibitor.

Consistent with these findings, $\gamma$-secretase inhibition resulted in a dose-dependent decrease in the percentage of cells showing positive cell nuclei-associated Notch1 and Notch2 immunoreactivity (Figs. $4 \mathrm{~A}, 4 \mathrm{~B}, 5 \mathrm{~g}, 5 \mathrm{j}$ ) from $41.3 \% \pm 3.1 \%$ to $12.5 \% \pm 2.4 \%$ and $25.8 \% \pm 3.1 \%$ to $13.3 \% \pm 3.5 \%$, respectively $(P<0.05)$. A concurrent increase in cell membrane-associated labeling (Figs. $4 \mathrm{~A}, 4 \mathrm{~B}, 5 \mathrm{~g}, 5 \mathrm{j}$ ) from $29.9 \% \pm 3.1 \%$ to $56.7 \%$

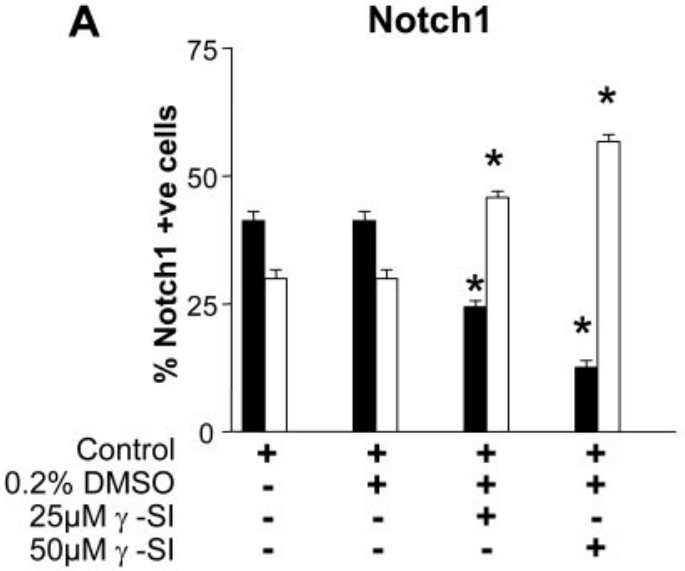

C Ki67

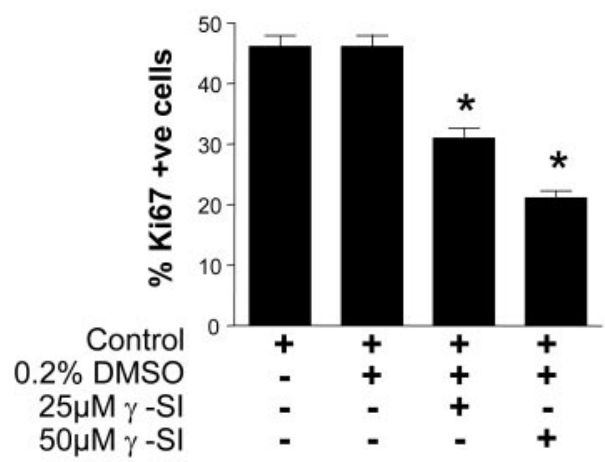

B

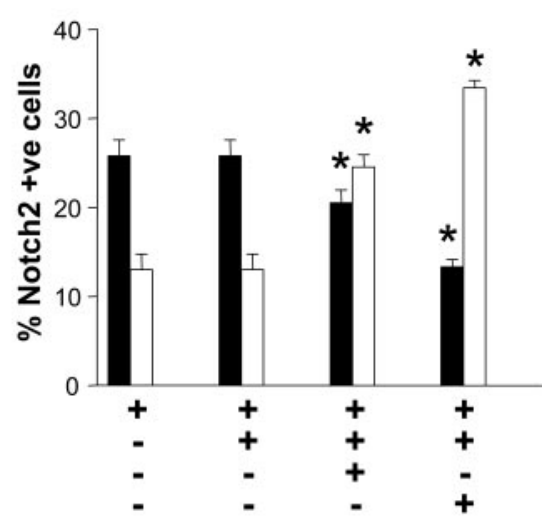

D

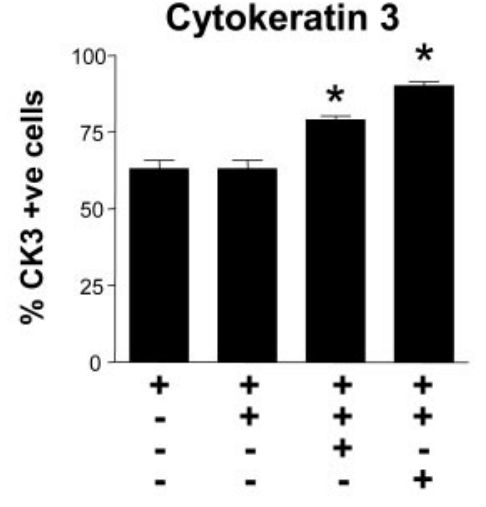

FIGURE 4. $\gamma$-Secretase inhibition of Notch1 and Notch2. Immunolocalization of Ki67 and CK3 in corneal epithelial cells. Cultured corneal epithelial cells were challenged with $25 \mu \mathrm{M}$ or $50 \mu \mathrm{M} \gamma$-secretase inhibitor $(\gamma$-SI) for 4 hours. Percentage cell nuclei (black) expressing Notch1 (A) and Notch2 (B) decreased, with a concurrent increase in percentage membrane-associated (white) Notch1 (A) and Notch2 (B) cell immunoreactivity. A decrease in Ki67-positive cells (C) and an increase in CK3-positive cells (D) were also observed. Control cells were incubated in media or media containing vehicle $(0.2 \%$ DMSO). ${ }^{*} P<0.05$. 

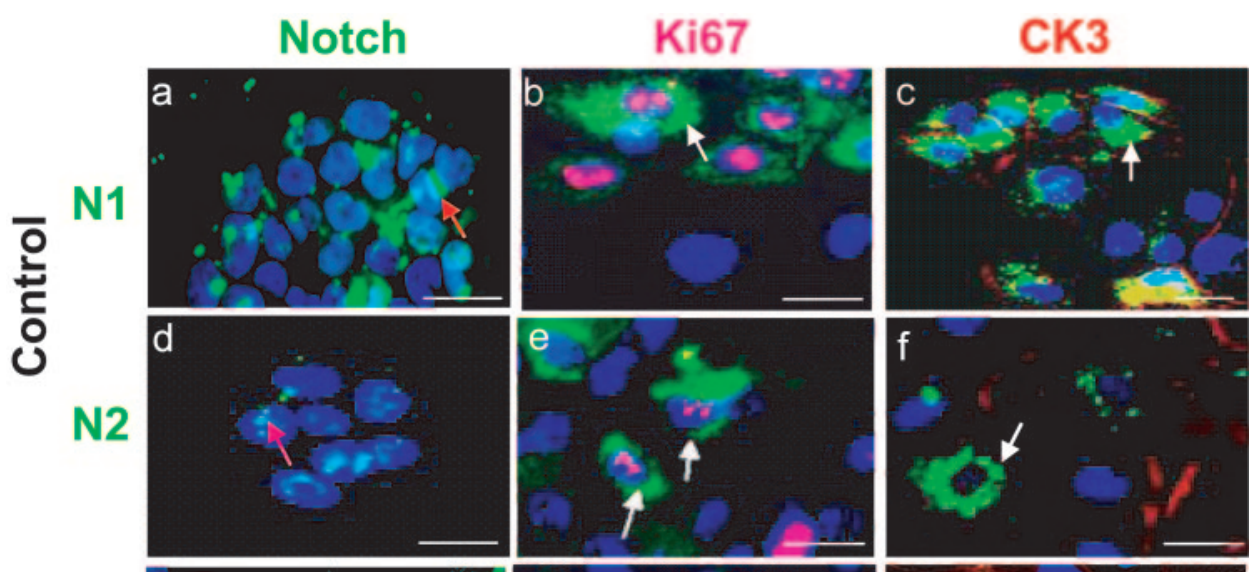

FiguRE 5. Effect of Notch inhibition $(50 \mu \mathrm{M} \gamma \mathrm{SI})$ and activation (10 $\mu \mathrm{g} / \mathrm{mL}$ Jagged1) on cellular expression of Notch1, Notch2, Ki67, and CK3. Corneal epithelial cells incubated with $\gamma$-secretase inhibitor or Jagged1. (a-f) Control cells (untreated media, with or without vehicle). (g-1) $\gamma$-Secretase inhibitortreated cells. (m-r) Jagged1-treated cells. Green: Notch1/Notch2; pink: Ki67; red: CK3; blue: Hoechst nuclear localization. White arrows: Cell membrane-associated Notch immunoreactivity. Red arrows: Notch immunoreactivity cell nuclei. Bars, $50 \mu \mathrm{m}$.
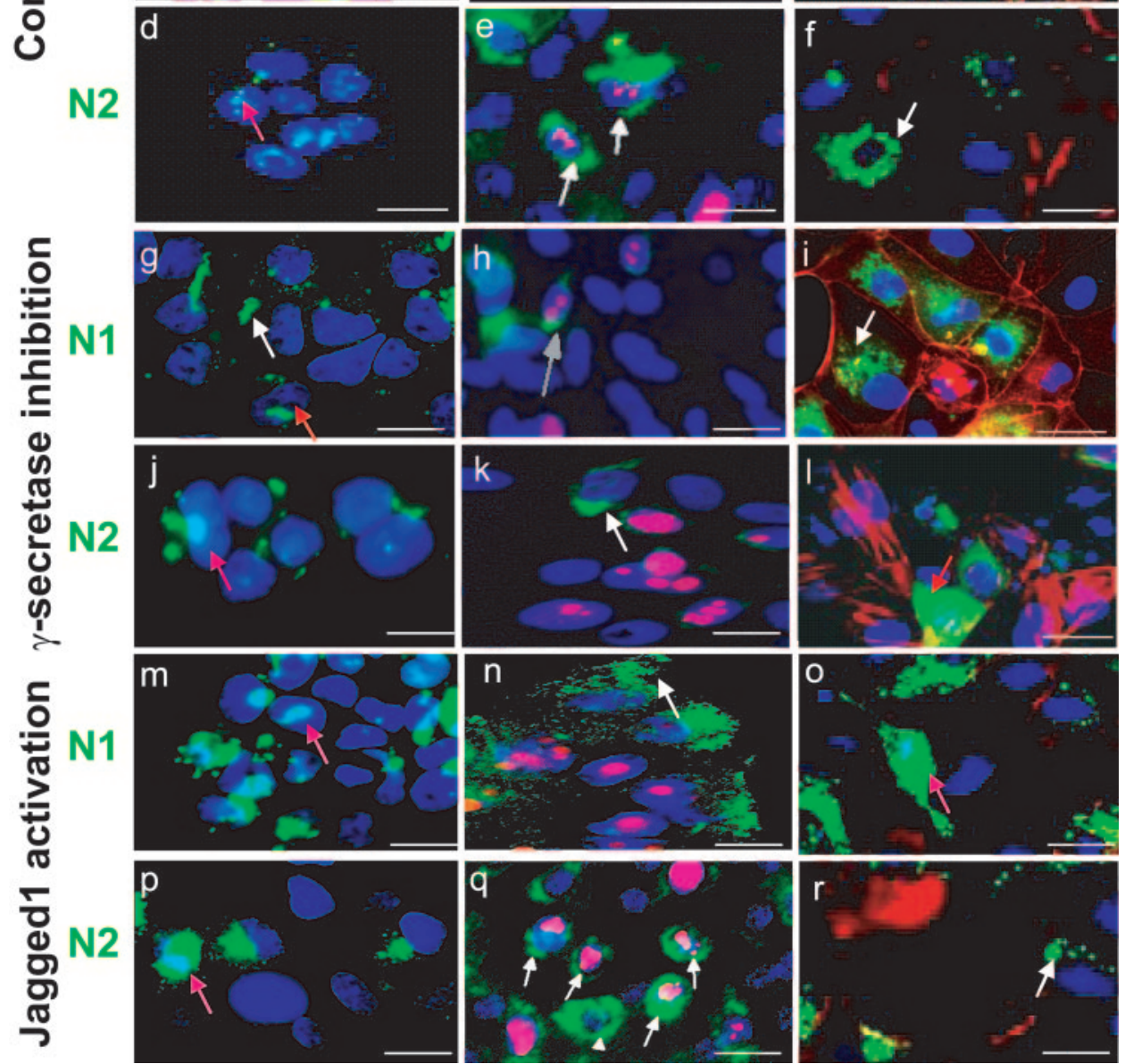

$\pm 2.4 \%$ cells (Notch1) and $13.0 \% \pm 3.1 \%$ to $33.4 \% \pm 3.5 \%$ (Notch2) was also identified $(P<0.05)$. An accompanying decrease in the percentage of cells expressing the proliferation marker Ki67 from $46.1 \% \pm 3.1 \%$ to $21.2 \% \pm 4.5 \%$ (Figs. $4 \mathrm{C}, 5 \mathrm{~h}$, $5 \mathrm{k}$ ) and increased CK3 immunoreactivity (Figs. 4D, 5i, 51) from $63.0 \% \pm 6.8 \%$ to $90.1 \% \pm 6.8 \%(P<0.05)$ was also noted.

\section{Activation of Notch Signaling Increased Epithelial Cell Proliferation and Decreased Differentiation}

Incubation of cultured corneal epithelial cells with rJagged1 resulted in increased expression of active isoforms Notch1120 and Notch2-85, with a concurrent decrease in the expression of full-length isoforms Notch1-300 and Notch2-85, respectively (Figs. 6A, 6B). These changes in Notch expression were accompanied by a significant increase in Ki67 (Fig. 6C) and decrease in CK3 (Fig. 6D). All effects were dose dependent, and all differences in expression were statistically significant after $5 \mu \mathrm{g} / \mathrm{mL}(P<0.05)$ and $10 \mu \mathrm{g} / \mathrm{mL}(P<0.05)$ Jagged1 treatment.

After Jagged1 activation, dose-dependent increased expression of cell nuclei-related Notch 1 immunoreactivity, from $41.3 \% \pm 3.1 \%$ to $82.6 \% \pm 5.1 \%$ cells $(P<0.05$; Figs.
$5 \mathrm{~m}, 7 \mathrm{~A})$, and of Notch2 immunoreactivity, from $25.8 \% \pm$ $3.1 \%$ to $63.8 \% \pm 3.1 \%$ cells $(P<0.05$; Figs. 5 p, $7 \mathrm{~B})$ was observed. In addition, concomitant decreases in cell membrane-associated labeling expression of Notch1 (Fig. 7A), from $29.9 \% \pm 3.1 \%$ to $6.7 \% \pm 4.4 \%$ cells $(P<0.05)$, and of Notch2 (Fig. 7B), from $13.0 \% \pm 3.1 \%$ to $3.7 \% \pm 3.5 \%$ cells $(P<0.05)$, were determined. This was noted to coincide with increased cell $\mathrm{Ki} 67$ positivity (Figs. 5 n, 5 q, $7 \mathrm{C}$ ), from $46.7 \% \pm$ $3.5 \%$ to $81.5 \% \pm 7.1 \%$ cells $(P<0.05)$ and with decreased CK3 immunoreactivity (Figs. 5o, 5r, 7D) from $63.0 \% \pm 6.8 \%$ to $18.1 \% \pm 6.5 \%$ cells $(P<0.05)$.

\section{Notch Signaling in Corneal Epithelial Stratification}

Morphologic appearance of human corneal epithelial cells during the air-lift stratification cultures indicated that with normal treatment, corneal epithelial cells formed five to six layers of stratified epithelium by 4 weeks (Fig. 8A1). Inhibition of Notch resulted in an increased number of epithelial cell layers (5-6 to 7-8; Figs. 8A2, 8B), with no change in the percentage of cells expressing the proliferative marker $\mathrm{Ki} 67$ and differentiation marker cytokeratin3 (Figs. 8C, 8D). By week 4, basal epithelial 
A Notch1
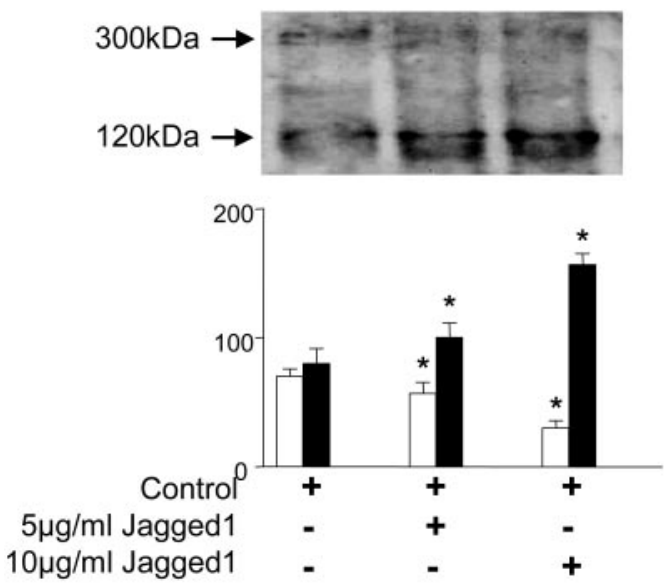

C

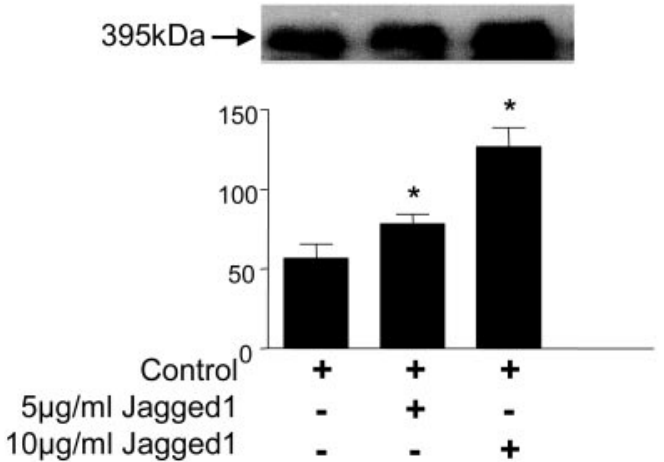

B

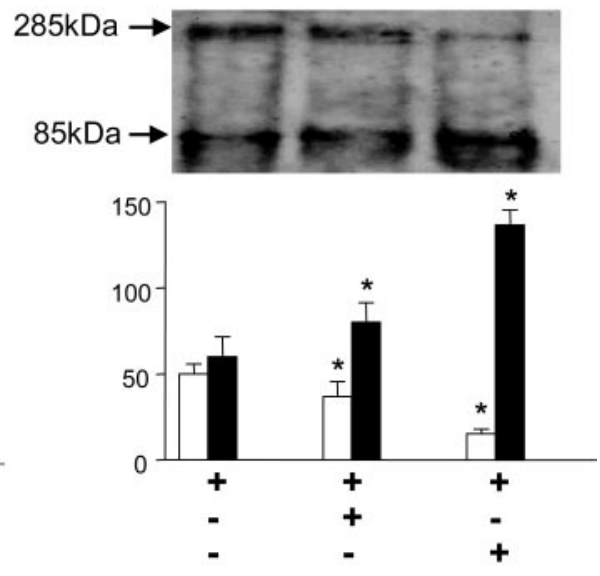

D
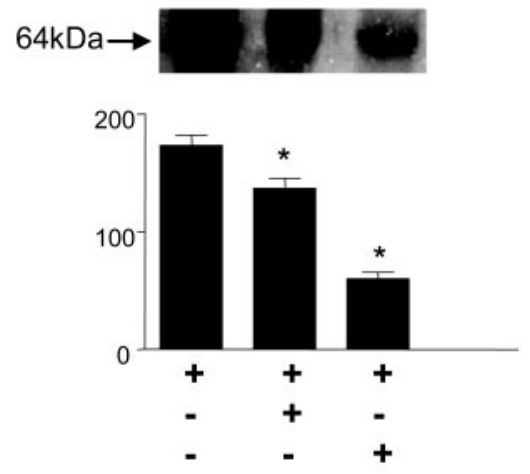

FIGURE 6. Jagged1 activation of Notch1 and Notch2 in corneal epithelial cells. Cultured corneal epithelial cells were incubated in 5 or 10 $\mu \mathrm{g} / \mathrm{mL}$ Jagged 1 or control media for 2 days. Lysates were resolved by SDSPAGE, and immunopositive bands were semiquantified by scanning laser densitometry. (A) Notch1 (fulllength: N1-300, white; NICD: N1120, black). (B) Notch2 (full-length: N2-285, white; NICD: N2-85, black). (C) Ki67. (D) CK3. Data are expressed as mean \pm SEM. ${ }^{*} P<$ 0.05 . cells were flatter and superficial cells appeared to slough off more easily from the surface layers (Fig. 8A2).

Notch activation resulted in reductions in epithelial cell layers (5-6 to 3-4; Figs. 8A3, 8B) and in cytokeratin3 expression (Fig. 8D; $P<0.05$ ) compared with control cultures. No change in the percentage of $\mathrm{Ki} 67$ cells was observed compared with controls (Fig. 8C). By week 4, the epithelial layer was thinner than control, and the cell nuclei appeared slightly larger (Fig. 8A3), suggesting fewer differentiated epithelial cells.

\section{Discussion}

Corneal epithelial cells turn over approximately every 7 to 14 days, continuously maintaining the stratified structure of the epithelium. Defining the mechanisms responsible for the differentiation and self-renewal of corneal epithelial cells is a prerequisite to achieving complete understanding of the process of corneal epithelial cell homeostasis and wound healing. One possible regulator is Notch signaling, which regulates cell fate in many different tissues in a wide range of organisms, including the nervous system, vascular system, hematopoietic system, somites, muscle, skin, and pancreas. ${ }^{2,24}$

This study has identified the presence of receptors and ligands known to play roles in Notch signaling in adult human corneal epithelium. Two Notch receptors (Notch1 and Notch2) and two Notch ligands (Delta1 and Jagged1) were identified in adult human corneal epithelial cells at the gene and protein levels, indicating that Notch signaling is likely to be involved in the orchestration of adult human corneal epithelial homeostasis. Notch1 and Notch2 were localized throughout the corneal epithelium in suprabasal cell layers.

In the Notch downstream pathway, $\gamma$-secretase cleaves the membrane-tethered Notch fragment within its transmembrane domain, ${ }^{14,15,24}$ resulting in the release of the intracellular domain (NICD) and translocation into the nucleus to participate in the transcriptional activation of target genes ${ }^{8,25}$ and subsequent downstream events. Notch signaling plays different roles in different tissues and within the same tissue at different developmental stages. ${ }^{2}$ In most cases, Notch signaling blocks a primary differentiation fate in a cell and forces the cell to remain in an undifferentiated state, and it can regulate terminal differentiation. 2, 26-29 However, recent evidence shows that Notch signaling can promote differentiation in some circumstances. $^{25,30}$

$\gamma$-Secretase inhibition of Notch cleavage prevents Notch signaling. ${ }^{14,30}$ Consistent with this finding, our results demonstrated decreased expression of the active NICD isoforms of Notch1 and Notch2 in human corneal epithelial cells, with a concomitant increase in full-length, membrane-bound isoforms. Functional changes in epithelial cells after $\gamma$-secretase inhibition were significantly reduced cell proliferation and increased cytokeratin 3 (CK3) expression. These results have two implications. One is that $\gamma$-secretase exists in human corneal epithelial cells and is involved in the mediation of Notch signaling, and the other is that $\gamma$-secretase 
A

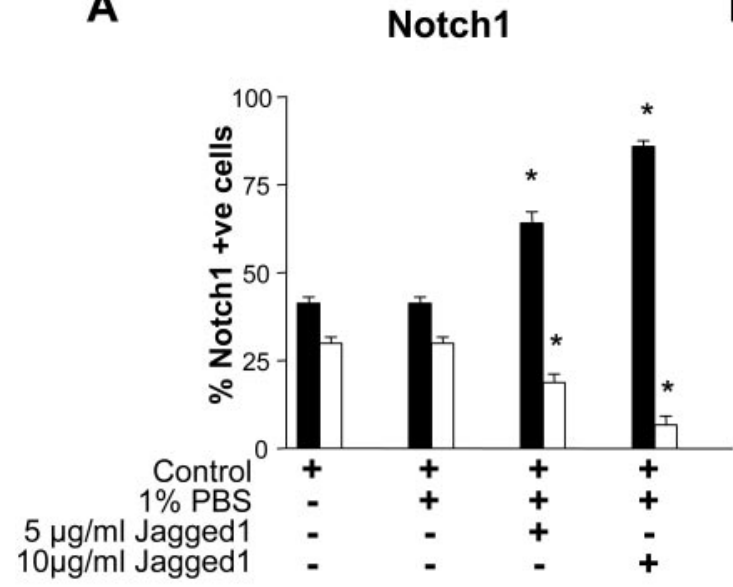

C

FIGURE 7. Jagged 1 activation of Notch1 and Notch2. Immunolocalization of $\mathrm{Ki} 67$ and $\mathrm{CK} 3$ in corneal epithelial cells. Cultured corneal epithelial cells were challenged with different concentrations of Jagged1 ( 5 and $10 \mu \mathrm{g} / \mathrm{mL}$ ) for 2 days. The percentage of cell nuclei (black) expressing (A) Notch1 and (B) Notch2 increased, with a decrease in the percentage of cells expressing membrane-associated (white) (A) Notch1 and (B) Notch2 immunoreactivity. An increase in (C) Ki67-positive cells and a decrease in (D) CK3-positive cells were also observed. Control cells were incubated in media or media containing vehicle. ${ }^{*} P<0.05$.
B

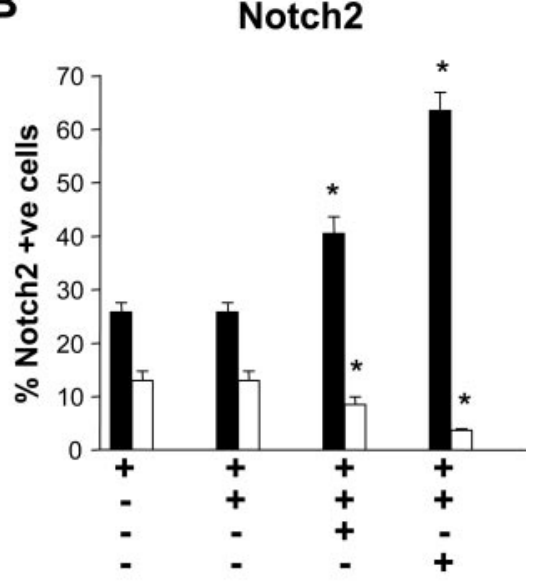

Ki67

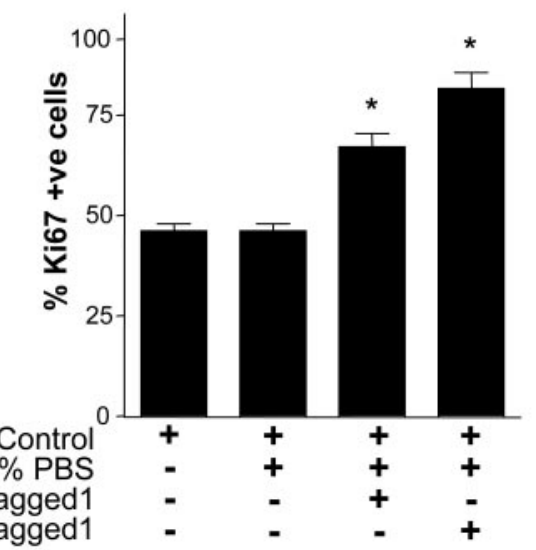

Cytokeratin 3

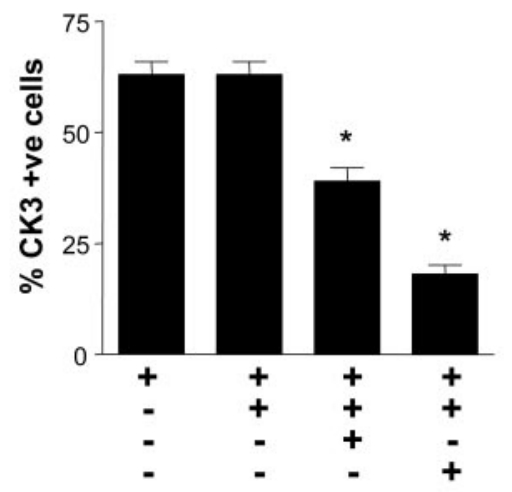

inhibition represses cell proliferation and promotes the differentiation of corneal epithelial cells in a manner consistent with the downregulation of Notch signaling. In contrast, Notch activation in human corneal epithelial cells by Jagged1, an established activator of the Notch downstream pathway, ${ }^{2,9}$ resulted in upregulation of the active isoforms of Notch 1 and 2, accompanied by an increase in epithelial cell proliferation and a decrease in CK3 expression. These results confirmed that Notch1 and Notch2 could be activated by Jagged 1 in corneal epithelial cells and that Jagged 1 activation of Notch could play a role in cell proliferation and epithelial differentiation.

It should be noted that $\gamma$-secretase cleaves other substrates, including CD44 and E-cadherin, which are present in the cornea, and the putative substrates amyloid precursor protein (APP) $)^{31-33}$ and low-density lipoprotein receptor-related protein (LRP). ${ }^{34}$ Thus, functional changes in epithelial cell homeostasis after $\gamma$-secretase inhibition in corneal epithelial cells may be a result of factors other than Notch. However, the presence of the Notch1 and Notch2 receptors and the ligands Delta1 and Jagged2, combined with the antagonistic effects of Jagged 1 activation and $\gamma$-secretase inhibition on Notch 1 and 2 isoform expression, cell proliferation, and differentiation in human corneal epithelial cells, strongly supports a role for Notch signaling in corneal epithelial cell homeostasis.

The involvement of Notch 1 and Notch2 in the regulation of human corneal epithelial cell homeostasis was further elucidated and characterized in vitro in a three-dimensional epithe- lial stratification model previously described by Connon et al. ${ }^{35}$ Notch signaling had a significant effect on corneal epithelial differentiation but had no effect on cell proliferation. Notch activation appeared to suppress the generation of differentiated epithelial cells, whereas inhibition of Notch signaling resulted in increased epithelial cell layers with no change in expression of the differentiation marker cytokeratin3. Interestingly, the cultures in the latter consisted of cells more likely to slough off from the multilayered epithelium. The different proliferative effects of Notch in the two-dimensional and threedimensional in vitro studies suggest that the functional Notch signaling pathway may be affected by its interaction with other signaling pathways, as has been shown in the in vivo state. ${ }^{2,36}$ In addition, signals-whether cell or matrix derived-in the three-dimensional stratification model might have been stronger than those of the Notch ligand or inhibitor such that other factors promoted cell proliferation to establish a multilayered epithelium, similar to that in a wound healing response.

This study supports a role for Notch signaling in the regulation of epithelial cell differentiation in corneal homeostasis, though its importance in the control of epithelial cell proliferation is controversial. Other researchers have revealed that Notch signaling, in addition to its well-established effects on cell differentiation, is implicated in cell proliferation ${ }^{2,37-39}$ and apoptotic events, ${ }^{2}$ though the elements mediating the nonautonomous effect of Notch on cell proliferation are unknown. It is likely that the proliferative effect of Notch signaling in 


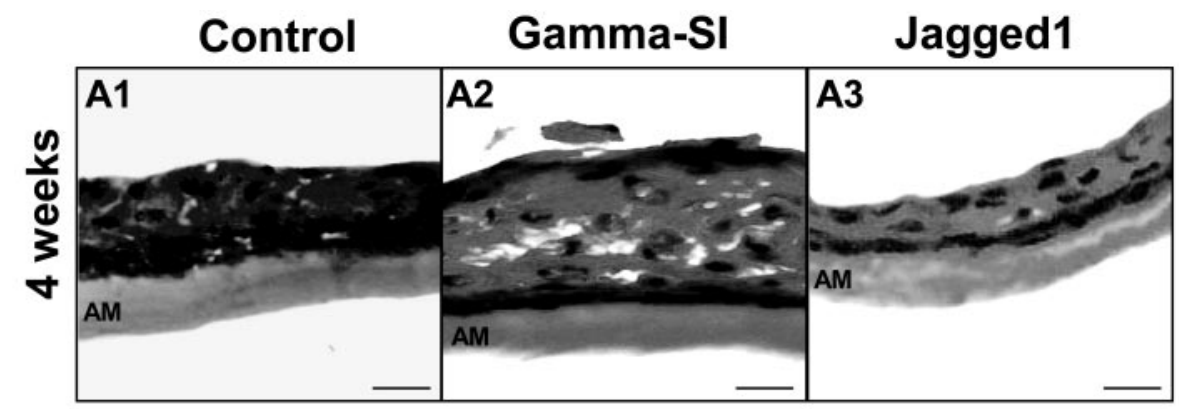

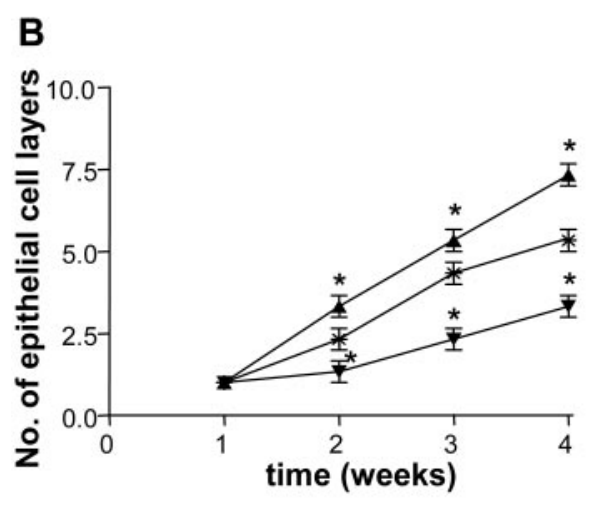

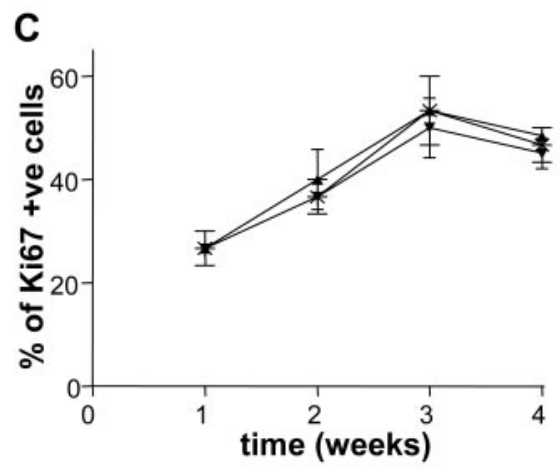

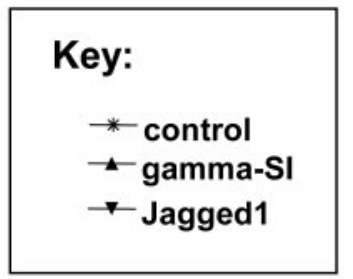

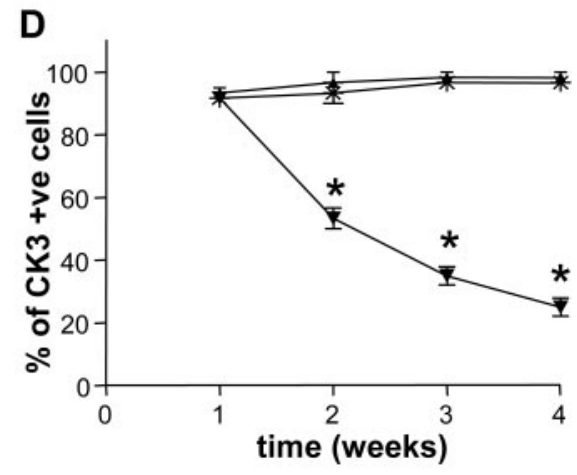

Figure 8. Effect of Notch inhibition (50 $\mu \mathrm{M} \gamma$-SI) and activation (10 $\mu \mathrm{g} / \mathrm{mL}$ Jagged1) on corneal epithelial cell stratification. (A1-A3) Corneal epithelial air-lift cultures after 4 weeks of culture. A1, control media; A2, $\gamma$-secretase inhibition; A3, Jagged1 activation. AM, amniotic membrane. Bars, $50 \mu \mathrm{m}$. (B) Graph depicting number of cell layers at different time points, after different treatments. (C) $\mathrm{Ki} 67$ and (D) CK3 expression in stratified corneal epithelium after Notch activation/inhibition in air-lift cultures: After $\gamma$-secretase inhibitor was added, a significant increase in the number of epithelial cell layers was observed (A2, B) compared with control cultures (A1, B; $\left.{ }^{*} P<0.05\right)$. However, $\gamma$-secretase inhibition had no significant effect on percentage (C) $\mathrm{Ki} 67$ or (D) CK3 immunopositive cells. Jagged 1 treatment resulted in a significant decrease in epithelial cell layers (A1, A3, B; $P<0.05$ ), accompanied by a significant decline in percentage CK3-positive cells at weeks 2, 3, and 4 (D; $P<0.05)$. (C) No change in the percentage Ki67 cells was observed compared with controls. different tissues may be the result of a synergistic effect between Notch and other proteins. ${ }^{2}$

A balance between cell proliferation and differentiation is essential for maintaining corneal epithelial homeostasis. The existence of Notch receptors and their ligands in the differentiated, nonproliferating suprabasal cell layers throughout the human corneal epithelium implicates Notch signaling in corneal epithelium differentiation and suggests preventing cell entry into the cell cycle. Indeed, previous studies have indicated that Notch1 acts as a tumor suppressor in mammalian skin. ${ }^{40}$

The lack of Notch receptor expression in the basal cell layers of the cornea and limbus, where transient amplifying cells appear, disputes a role for Notch in the in vivo induction of cell proliferation. The mechanism for acquiring the proliferative function of Notch may be reprogrammed or inhibited, or it may be related to the specific location of basal cells and their contact with basement membrane. It may be that in vitro, the removal of cells from the in vivo state isolates the cells from the cell-cell or cell-matrix contacts that prevent entry into the cell cycle.

Similar protein expression patterns of Notch1 have been found in other epithelia, including the human epidermis, and in mucosae of the oral cavity, esophagus, ectocervix, and vagina. ${ }^{41}$ In such structures, it is thought that the exclusion of Notch 1 from the dead external surface cells implies a function of Notch in regulating epithelial maturation. In fact, this may be the case in the human corneal epithelium, with Notch in suprabasal cells regulating epithelial differentiation such that terminal differentiation is inhibited. Indeed, Notch 1 inactivation by tissue-specific gene targeting has demonstrated that such inactivation in the mouse cornea induces keratinization. ${ }^{40}$

Overall, the expression of Notch receptors and ligands in the human corneal epithelium and the functional associations among the expression of active and inactive Notch isoforms and cell status shown in this study suggest Notch signaling has a pivotal role in the maintenance of corneal epithelial cell homeostasis.

\section{Acknowledgments}

The authors thank Bristol Eye Bank for providing human research tissue, with an established lack of objection for research use. They also thank the National Eye Research Center, UK, for its support. 


\section{References}

1. Greenwald I. LIN-12/Notch signaling: lessons from worms and flies. Genes Dev. 1998;12:1751-1762.

2. Artavanis-Tsakonas S, Rand MD, Lake RJ. Notch signaling: cell fate control and signal integration in development. Science. 1999;284: $770-776$

3. Kopan R, Turner DL. The Notch pathway: democracy and aristocracy in the selection of cell fate. Curr Opin Neurobiol. 1996;6: 594-601.

4. del Amo FF, Gendron-Maguire M, Swiatek PJ, Jenkins NA, Copeland NG, Gridley T. Cloning, analysis, and chromosomal localization of Notch-1, a mouse homolog of Drosopbila Notch. Genomics. 1993; 15:259-264.

5. Lardelli M, Lendahl U. Motch A and Motch B-two mouse Notch homologues coexpressed in a wide variety of tissues. Exp Cell Res. 1993;204:364-372.

6. Lardelli M, Williams R, Mitsiadis T, Lendahl U. Expression of the Notch 3 intracellular domain in mouse central nervous system progenitor cells is lethal and leads to disturbed neural tube development. Mech Dev. 1996;59:177-190.

7. Uyttendaele H, Marazzi G, Wu G, Yan Q, Sassoon D, Kitajewski J. Notch4/int-3, a mammary proto-oncogene, is an endothelial cellspecific mammalian Notch gene. Development. 1996;122:22512259.

8. Jarriault S, Brou C, Logeat F, Schroeter EH, Kopan R, Israel A. Signalling downstream of activated mammalian Notch. Nature. 1995;377:355-358.

9. Lindsell CE, Shawber CJ, Boulter J, Weinmaster G. Jagged: a mammalian ligand that activates Notch1. Cell. 1995;80:909-917.

10. Luo B, Aster JC, Hasserjian RP, Kuo F, Sklar J. Isolation and functional analysis of a cDNA for human Jagged2, a gene encoding a ligand for the Notch1 receptor. Mol Cell Biol. 1997;17:60576067.

11. Shimizu K, Chiba S, Hosoya N, et al H. Binding of Delta1, Jagged1, and Jagged 2 to Notch2 rapidly induces cleavage, nuclear translocation, and hyperphosphorylation of Notch2. Mol Cell Biol. 2000; 20:6913-6922.

12. Shimizu K, Chiba S, Kumano K, et al. Mouse Jagged1 physically interacts with Notch2 and other Notch receptors: assessment by quantitative methods. J Biol Chem. 1999;274:32961-32969.

13. Brou C, Logeat F, Gupta N, et al. A novel proteolytic cleavage involved in Notch signaling: the role of the disintegrin-metalloprotease TACE. Mol Cell. 2000;5:207-216.

14. De Strooper B, Annaert W, Cupers P, et al. A presenilin-1-dependent gamma-secretase-like protease mediates release of Notch intracellular domain. Nature. 1999;398:518-522.

15. Struhl G, Greenwald I. Presenilin is required for activity and nuclear access of Notch in Drosophila. Nature. 1999;398:522-525.

16. Ye Y, Lukinova N, Fortini ME. Neurogenic phenotypes and altered Notch processing in Drosopbila presenilin mutants. Nature. 1999;398:525-529.

17. Mumm JS, Schroeter EH, Saxena MT, et al A ligand-induced extracellular cleavage regulates gamma-secretase-like proteolytic activation of Notch1. Mol Cell. 2000;5:197-206.

18. Klyce SD. Electrical profiles in the corneal epithelium. J Physiol. 1972;226:407-429.

19. Kruse FE, Volcker HE. Stem cells, wound healing, growth factors, and angiogenesis in the cornea. Curr Opin Opbthalmol. 1997;8: 46-54.

20. McKechnie NM, Boulton M, Robey HL, Savage FJ, Grierson I. The cytoskeletal elements of human retinal pigment epithelium: in vitro and in vivo. $J$ Cell Sci. 1988;91(pt 2):303-312.
21. Wolfe MS, Xia W, Moore CL, et al. Peptidomimetic probes and molecular modeling suggest that Alzheimer's gamma-secretase is an intramembrane-cleaving aspartyl protease. Biochemistry. 1999; 38:4720-4727.

22. Gerdes J, Lemke H, Baisch H, Wacker HH, Schwab U, Stein H. Cell cycle analysis of a cell proliferation-associated human nuclear antigen defined by the monoclonal antibody Ki-67. J Immunol. 1984;133:1710-1715.

23. Schermer A, Galvin S, Sun TT. Differentiation-related expression of a major $64 \mathrm{~K}$ corneal keratin in vivo and in culture suggests limbal location of corneal epithelial stem cells. J Cell Biol. 1986;103:4962.

24. Song W, Nadeau P, Yuan M, Yang X, Shen J, Yankner BA. Proteolytic release and nuclear translocation of Notch-1 are induced by presenilin-1 and impaired by pathogenic presenilin-1 mutations. Proc Natl Acad Sci USA. 1999;96:6959-6963.

25. Fortini ME. Notch and presenilin: a proteolytic mechanism emerges. Curr Opin Cell Biol. 2001;13:627-634.

26. Gray GE, Mann RS, Mitsiadis E, et al. Human ligands of the Notch receptor. Am J Patbol. 1999;154:785-794.

27. Bigas A, Martin DI, Milner LA. Notch1 and Notch2 inhibit myeloid differentiation in response to different cytokines. Mol Cell Biol. 1998; 18:2324-2333

28. Capobianco AJ, Zagouras P, Blaumueller CM, Artavanis-Tsakonas S, Bishop JM. Neoplastic transformation by truncated alleles of human Notch1/Tan1 and Notch2. Mol Cell Biol. 1997;17:6265-6273.

29. Frise E, Knoblich JA, Younger-Shepherd S, Jan LY, Jan YN. The Drosophila Numb protein inhibits signaling of the Notch receptor during cell-cell interaction in sensory organ lineage. Proc Natl Acad Sci USA. 1996;93:11925-11932.

30. Wolfe MS. $\gamma$-Secretase inhibitors as molecular probes of presenilin function. J Mol Neurosci. 2001;17:199-204.

31. Selkoe DJ. Translating cell biology into therapeutic advances in Alzheimer's disease. Nature. 1999;399:A23-A31.

32. Steiner $\mathrm{H}$, Haass C. Intramembrane proteolysis by presenilins. Nat Rev Mol Cell Biol. 2000;1:217-224.

33. De Strooper B, Annaert W. Proteolytic processing and cell biological functions of the amyloid precursor protein. J Cell Sci. 2000; 113:1857-1870.

34. Fortini ME. Gamma-secretase-mediated proteolysis in cell-surfacereceptor signalling. Nat Rev Mol Cell Biol. 2002;3:673-684.

35. Connon CJ, Kawasaki S, Liles M, et al. Gene expression and immunolocalisation of a calcium-activated chloride channel during the stratification of cultivated and developing corneal epithelium. Cell Tissue Res. 2006;323:177-182.

36. Chu J, Jeffries S, Norton JE, Capobianco AJ, Bresnick EH. Repression of activator protein-1-mediated transcriptional activation by the Notch-1 intracellular domain. J Biol Chem. 2002;277:75877597.

37. Go MJ, Eastman DS, Artavanis-Tsakonas S. Cell proliferation control by Notch signaling in Drosopbila development. Development. 1998; 125:2031-2040.

38. Cagan RL, Ready DF. Notch is required for successive cell decisions in the developing Drosophila retina. Genes Dev. 1989;3: 1099-1112

39. de Celis JF, Tyler DM, de Celis J, Bray SJ. Notch signalling mediates segmentation of the Drosophila leg. Development. 1998;125: 4617-4626.

40. Nicolas M, Wolfer A, Raj K, et al. Notch1 functions as a tumor suppressor in mouse skin. Nat Genet. 2003;33:416-421.

41. Baldi A, De Falco M, De Luca L, et al. Characterization of tissue specific expression of Notch-1 in human tissues. Biol Cell. 2004; 96:303-311. 